\title{
Var Brandes prædadaist?
}

\section{Staatsbibliothek zu Berlin, Sturm-Archiv, Herwarth Walden samt nogle breve fra Georg Brandes, Herman Bang og Johannes V. Jensen}

af mag.art. Ursula Fugmann

I Sturm-Archiv i Berlin blandt 3.600 breve fra 200 afsendere, fordelt i 10 store papkasser, dukker der en kortfattet besked op fra Georg Brandes til Herwarth Walden. Brandes skriver 13. september 1906: "Hochgeehrter Herr, Ich ahnte nicht, dass Ihr Verein jung ist und keine Geschäfte macht ... Aber ich komme doch nicht zu Berlin. Ich habe nicht das geringste Vergnügen daran, öffentlich zu reden." Blandt brevene ligger der sandelig også tre fra Herman Bang og to fra Johannes V. Jensen.

Sturm-Archiv med de 3.600 breve og dette lille stykke dansk-tysk kulturhistorie befinder sig i Staatsbibliothek zu Berlin, Preussischer Kulturbesitz, med adressen Potsdamerstrasse 33. Brevene fra Georg Brandes, Herman Bang og Johannes V. Jensen er alle reaktioner på indbydelser fra Herwarth Walden til at læse op af egne værker i den af ham stiftede Verein für Kunst i Berlin.

Herwarth Walden er ikke kendt for Verein für Kunst, men som udgiver af det legendariske tidsskrift Der Sturm, som kom på gaden i Berlin 1910. Nøjagtigt fra dette tidspunkt var tidsskriftet et af de vigtigste talerør for den tyske ekspressionisme og den tyske og internationale avantgarde. Tidsskriftet gik ind i 1932, som en konsekvens af de politiske begivenheder i Tyskland. De danske breve stammer fra perioden 1906-1908, altså umiddelbart før Der Sturm begyndte at udkomme.

Sturm-Archivs skæbne er højst dramatisk. Da jeg i 1984 opdagede brevene i Berlin, undersøgte jeg nogle forhold omkring Herwarth Walden. Arkivet var på det tidspunkt tilgængeligt i nogle store kasser, de såkaldte Marburgerkasser.

$\mathrm{Nu}$ er arkivets bestand katalogiseret og i nogle tilfælde mikrofilmet, så det ikke mere er muligt sådan at rode i selve kasserne. - I forbindelse med et besøg i Berlin i 1994 bestilte jeg brevene frem og fik dem kopieret. 


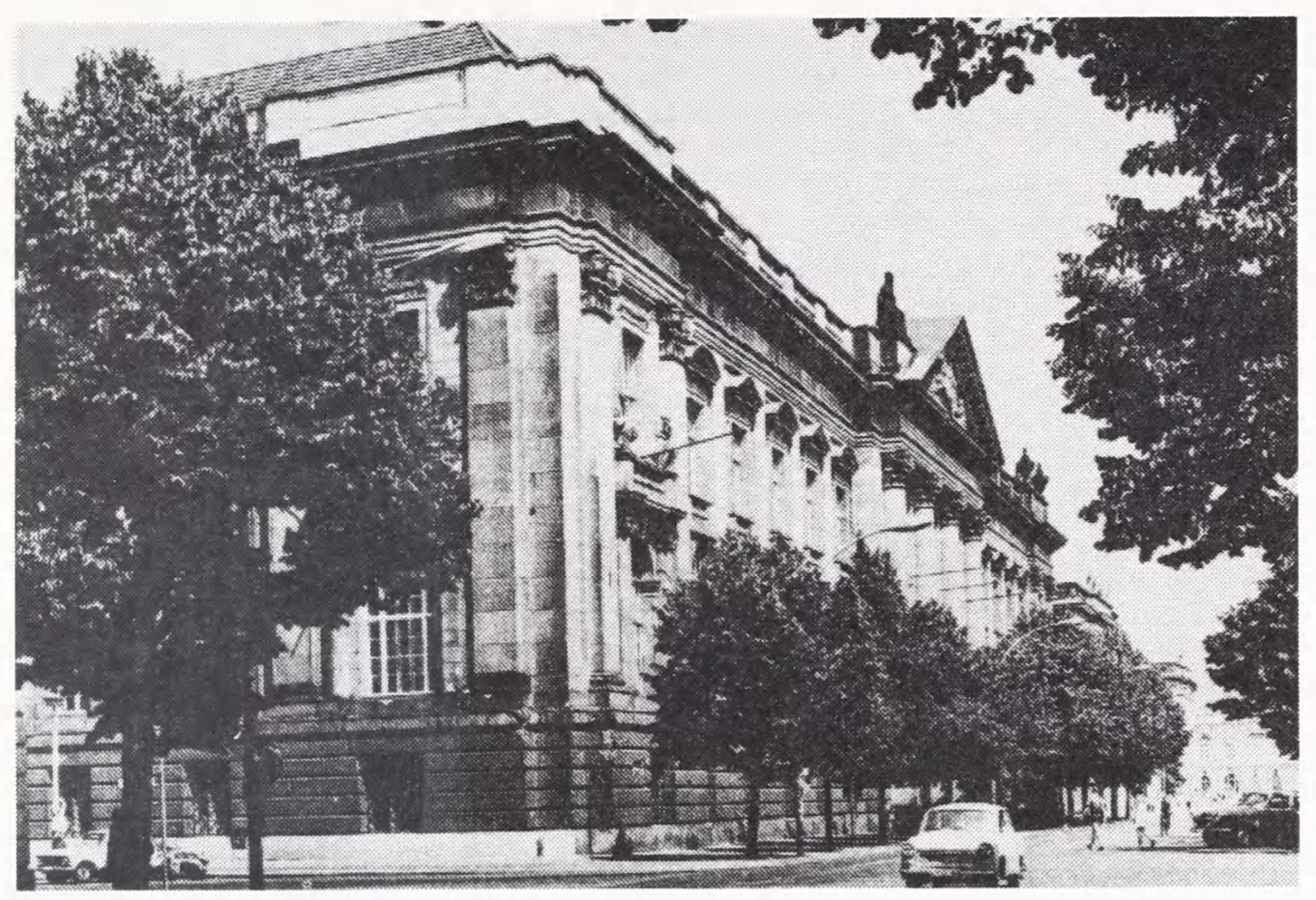

Staatsbibliothek zu Berlin. Biblioteket var i DDR-tiden universitetsbibliotek for HumboldtUniversität.

\section{Biblioteket og arkivet}

For at forstå begrebet Marburgerkasser er det nødvendigt at give et kort rids af Staatsbibliotheks og Sturm-Archivs skæbne. Staatsbibliothek zu Berlin, Hans Scharouns ekspressive bygning (1967-78), er en af efterkrigstidens største biblioteksbygninger. Den er en del af det af Hans Scharoun planlagte „Kulturbandes“, et museums- og kulturcenter, en slags kulturbånd fra Charlottenburg til Museumsinsel. Dette blev totalt forpurret, da Muren blev opført. Den første bygning, der blev opført på de udbombede tomter ved Potsdamer Strasse/Potsdamer Platz, var Scharouns Philharmonie i 1960-63. Senere kom Mies van der Rohes Neue Nationalgalerie til, opført 1965-68, og så Staatsbibliothek, der stod færdig i 1978. Dette kulturcentrum, der går under navnet Kulturforum Tiergarten eller Kulturforum am Kemperplatz, blev højaktuelt ved Murens fald og genforeningen med de medfølgende sammenføjninger af museernes, bibliotekernes og arkivernes bestand fra Øst- og Vestberlin. Frem til begyndelsen af 1990'erne mindede bygningerne på tomterne mest af alt om atlanterhavsdampere på kollisionskurs, hvad der forhåbentlig ændrer sig, når Kulturforum er færdigt. Idag er området udvidet med Kunstgewerbemuseum 1978-84 (Rolf Gutbrod), Kunstbibliothek og Kupferstichkabinett 1987-93 (Gutbrod, Hilmer \& Sattler), samt Museen der europäischen Kunst (Hilmer \& Sattler), der er under opførelse. Hans Scharouns biblioteksbygning blev efter Berlins deling opført som erstatning for Preussische Staatsbibliothek på Unter den Linden, opført 1903-14 efter udkast af Ernst von Ihne, oprindeligt 
Staatsbibliothek zu Berlin.

Opført på

Potsdamer

Strasse

(Vestberlin) efter Berlins deling, som erstatning for Preussische Staatsbibliotek

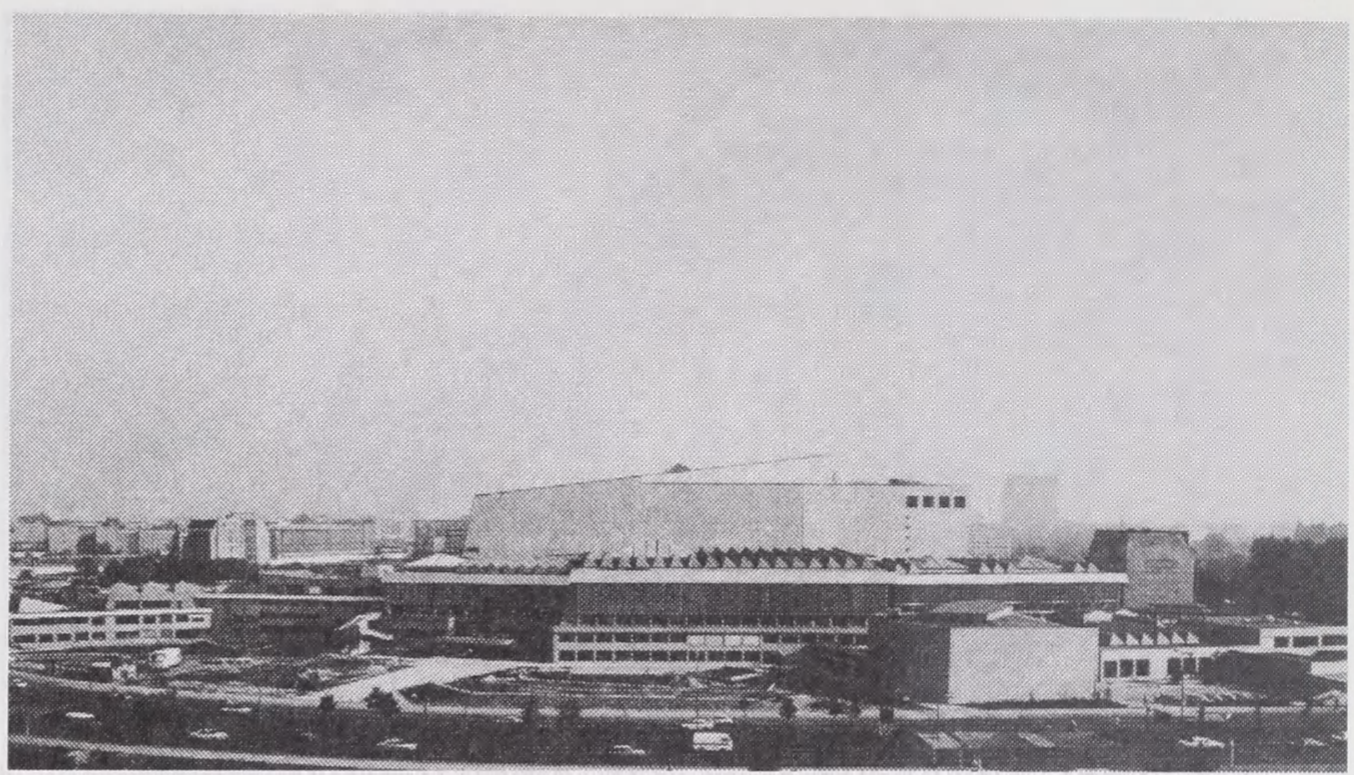

Königliche Bibliothek, fra 1918 Preussische Staatsbibliothek. I mellemkrigsårene havde biblioteket status som det mest betydningsfulde universalbibliotek i Tyskland. Under DDR regimet tjente det som bibliotek for Humboldt-Universität og for Akademie der Wissenschaften.

Sturm-Archiv blev iflg. håndskriftsafdelingens accessionsprotokol solgt til Preussische Staatsbibliothek af Herwarth Walden 19. august 1926, få år før han i 1932 emigrerede til det daværende Sovjet, på flugt for nationalsocialismen. Her omkom han ifølge de officielle meddelelser i koncentrationslejr 1941, som offer for Stalinterrorismen. Under 2. Verdenskrig blev Staatsbibliotheks vældige bestand bragt i sikkerhed og udstationeret 29 forskellige steder i Tyskland. Sturm-Archiv tilbragte perioden i Westdeutsche Bibliothek i Marburg. Her blev det gennemset og anbragt i 10 store papkasser. Da Marburg befandt sig i det kommende Vesttyskland, tilfaldt arkivet naturligt Vestberlin, hvor det siden åbningen af Scharouns Staatsbibliothek 1978 har været tilgængeligt i dettes håndskriftsafdeling. Efter genforeningen 2. januar 1992 blev de to biblioteker forenet som ét bibliotek i to huse under navnet Staatsbibliothek zu Berlin - Preussischer Kulturbesitz. Når bygningen på Unter den Linden er sat i stand, er det meningen, at den skal huse bestanden fra før 1955 af håndskrifter, kort og musiksamling og indrettes til forskningsbibliotek. Scharouns bygning skal huse bestanden efter 1955, regionalsamlinger for Østeuropa, Orienten og Asien og fungere som udlåns- og informationsbibliotek m.m. Sturm-Archiv vil hermed returnere til sit oprindelsessted på Unter den Linden.

Sturm-Archiv er et såkaldt „ægte“ litteratur- og kunstarkiv, organisk vokset ud af Herwarth Waldens litterære, journalistiske og organisatoriske virksomhed. Bestanden starter lige efter århundredeskiftet og slutter med årene 1918/19. Dokumen- 
terne fra tiden fra 1910 omhandler kunst- og litteraturrevolutionen med ekspressionismen, kubismen og dadaismen. Korrespondancen handler fra da af ikke så meget om litteratur, men om billedkunst. For at give et eksempel på arkivets rækkevidde, så møder vi, for at nævne de kendeste: Guillaume Apollinaire, Umberto Boccioni, Blaise Cendrars, Alfred Döblin ( 44 breve), August Stramm ( 73 breve), Wassily Kandinsky ( 73 breve), Paul Klee (15 breve), Filippo Tomaso Marinetti, Oscar Kokoschka; Max Liebermann; Gustav Mahler; Rainer Maria Rilke; Arnold Schön-berg; Kurt Schwitters; Frank Wedekind; Stephan Zweig; Karl Kraus; Adolf Loos; Julius MeierGraefe og blandt mange flere så også Georg Brandes, Herman Bang og Johannes V. Jensen.

\section{Manden}

Den legendariske Herwarth Walden blev født i Berlin 16.9. 1878. Han var af jødisk afstamning og hed oprindeligt Georg Lewin. Han var uddannet komponist og pianist hos den dengang feterede Conrad Ansorge, der arbejdede i den senromantiske Lizstskole, og dette skaffede den unge Lewin et Franz-Liszt stipendium med studieophold i Firenze 1897-98. Han gav senere musikundervisning og koncerter i de berlinske kunstnerfællesskaber, de livsreformistiske bevægelser som Die Kommenden og Neue Gemeinschaft, hvis grundstamme var tidligere naturalister fra den såkaldte Friedrichhagener Dichterkreis: Heinrich og Julius Hart, Bruno Wille, Wilhelm Bölsche, Karl Henckell, Felix

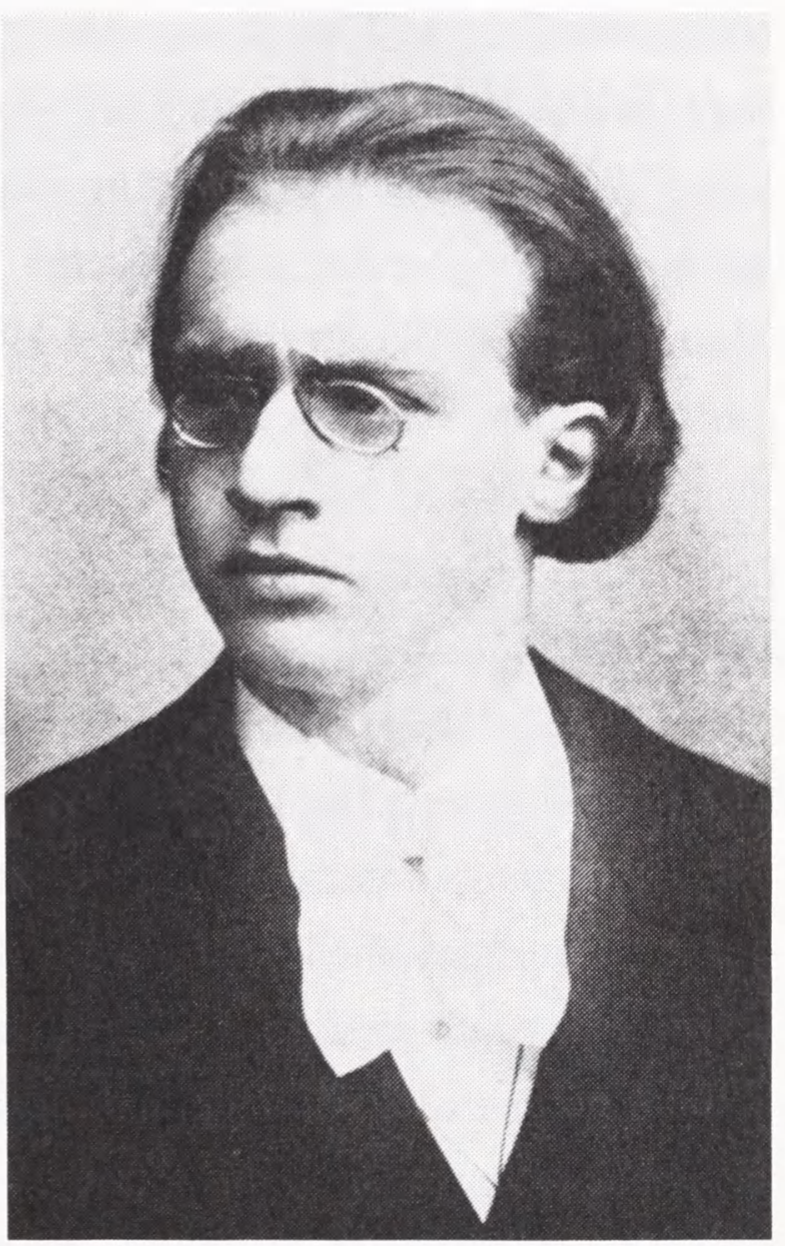

Herwarth Walden i 1903. Holländer, Albert Weidner, Wilhelm Spohr og Gustav Landauer. Til Waldens faste vennekreds i Neue Gemeinschaft hørte digterne Peter Hille, Paul Scheerbart, Else Lasker-Schüler, samt anarkisten Erich Mühsam. Heinrich Hart karakteriserer kredsen således: 
"Wir sind Atheisten und Theisten, Aristokraten und Demokraten, Kommunisten und Individualisten, esoterisch und eksoterisch, Mystiker und Positivisten, wir sind beides zugleich und beides wiederum nicht ..."

Neue Gemeinschaft var den største af de berlinske livsreformistiske bevægelser af hvilke der i Berlin kan registreres tretten på dette tidspunkt. Medlemmerne var intellektuelle, forfattere, komponister, billedkunstnere, socialister og anarkister. Litteraturhistorisk var det den sennaturalistiske og symbolistiske periode lige før overgangen til ekspressionismen; disse folk går under samlebegrebet Die berliner Moderne. Walden giftede sig med den jødiske digterinde Else Lasker-Schüler i 1901. Sammen startede de tidsskriftet Der Sturm i 1910, i begyndelsen tænkt som et kulturtidsskrift, med hovedvægt på litteratur. Men allerede i tidsskriftets første leveår blev Herwarth Walden indfanget af de nye udtryk indenfor maleri, blandt andet Oscar Kokoschkas kunst, som han stiftede bekendskab med ved dennes besøg i Berlin i 1910 og lidt senere af de italienske futuristers. Der Sturm blev fra dette tidspunkt tidskriftet for den tyske og internationale avantgarde, og Herwarth Walden kendt som Wegbereiter der Moderne. Der Sturm blev senere udvidet med Der Sturmgalerie og Der Sturm Verlag. I 1913 arrangerede Walden den banebrydende udstilling Erster deutscher Herbstsalon, en af de mest betydningsfulde udstillinger for international nutidskunst før 1 . verdenskrig.

\section{Foreningen}

Men tilbage til 1904, hvor Verein für Kunst startede som en udløber af kontakterne fra Neue Gemeinschaft. Grundlæggelsen af Verein für Kunst var det første udslag af Waldens organisationstalent, hvor han samlede den sig stadig udvidende berlinerog wienerkreds af intellektuelle, musikere, forfattere, digtere og billedkunstnere. Foreningen vandt efterhånden ry $i$ avantgardekredse som et af tidens mest konsekvente kunstneriske foretagender. Bevaret er Verein für Kunsts indbydel-sesbrev. I brevet til kunstnere står blandt andet:

Im nächsten Winter werden in 14 tägigem Turnus 14 Abende veranstaltet, an denen nur wirkliche Kunstler mitwirken werden. Jeder Abend ist nur einer Persönlichkeit gewidmet, und der Autor soll selbst seine werken vortragen oder höchstens durch einen von ihm gewählten Rezitator noch unterstüzt werden. Auch die Auswahl von seinen Werken soll dem Dichter oder unter Umständen dem Tondichter selbst überlassen bleiben. Wir können aus den Einnahmen dem Autor ein Honorar von 
100 Mark gewähren. Nach Abzug aller Unkosten würde sich immer noch bei selbst mittelmässigem Besuche ein Überschuss von ungefähr 100 Mark ergeben, der sonst den Agenten verfällt. Diese Überschüsse sollen gespart werden, um im nächstfolgenden Winter Kapital zu grösseren Veranstaltungen zur Verfügung zu haben.

Wir denken zum Beispiel an Aufführungen sogenannter „unaufführbaren“ dramatischer Werke und an Ankauf guter zeitgenössischer Literatur zur freien Verteilung an Volksbibliotheken etc. ... Wir behalten uns jedoch vor, auch neuen Talenten, die zugleich schon Könner sind, auf diese Weise den Weg in die öffentlichkeit zu erleichtern ... Die Veranstaltungen finden im Berliner Architektenhause statt ..."

Sandsynligvis har det været denne formulering, der har stået i den indbydelse, som Walden sender til Brandes, Bang og Jensen. "Nur wirkliche Künstler ..", står der. Man kan danne sig et billede af kvalitetsniveauet og derved indkredse, hvad Walden mener med en virkelig stor kunstner ved at se på en række af de personer, der har optrådt i Verein für Kunst: Peter Altenberg, Hermann Bahr, Peter Behrens, Peter Baum, Max Brod, Lovis Corinth, Richard Dehmel, Alfred Döblin, Julius Hart, Peter Hille, Arno Holz, Josef Kainz, Harry Graf Kessler, Karl Kraus, Else Lasker-Schüler, Adolf Loos, Heinrich und Thomas Mann, Alfred Mombert, Rainer Maria Rilke, Ludwig Rubiner, Paul Scheerhart, Johannes Schlaf, Henry van de Velde, Jacob Wassermann, og Frank Wedekind ...

Når Walden i indbydelsesbrevet omtaler "nur wirkliche Künstler" mener han sandsynligvis de allerede kendte i berliner-og wienerkredse: Wiener Bohemen, digteren Peter Altenberg; stifteren af wienersezessionen Hermann Bahr; den banebrydende berlinerarkitekt og forløber for funktionalismen Peter Behrens; wienerarkitekten tjekken Adolf Loos, hvis skrift Ornament und Verbrechen senere blev kampskrift for funktionalismen; den østriske forlægger, tjekken Karl Kraus, hvis ét mands tidsskrift Die Fackel sørgede for sprogets renselse; tjekken Max Brod, fra „Prager Kreis“, åndsbeslægtet og ven med Franz Kafka og fri forfatter og dramaturg; berlinermaleren, sezessionisten Lovis Corinth; forfatterne Richard Dehmel og Alfred Döblin, der senere skrev Berlin Alexanderplatz; den jødiske berlinske digterinde Else LaskerSchüler, der skrev den tyske ekspressionismes største digte; Thomas Mann og Rilke taler for sig selv; Jugendstilarkitekten Henry van de Velde; samt forfatteren, kabaretisten og dramatikeren Frank Wedekind fra München osv. Der er verdenshistorisk vingesus over den kreds, som også har dansk islæt, i form af Georg Brandes, Herman Bang og Johannes V. Jensen. 

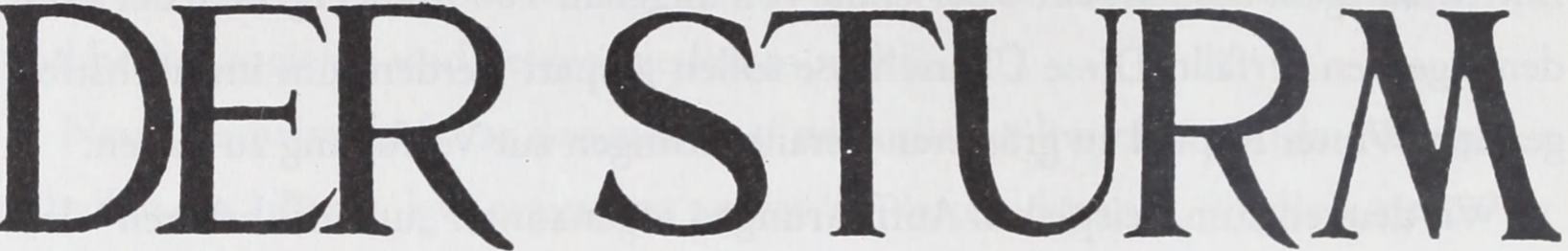

WOCHENSCHRIFT FÜR KULTUR UND DIE KÜNSTE

\begin{tabular}{|c|c|c|}
\hline 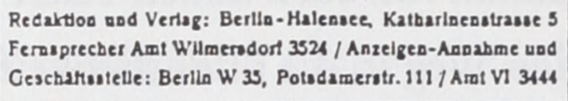 & $\begin{array}{l}\text { Herauseber uod Schrlitielier: } \\
\text { HERWARTH WALDEN }\end{array}$ & $\begin{array}{l}\text { Vierteljabresbezug 1,25 Mark ; Habjabreabezug } 250 \text { Mark / } \\
\text { Jabreabezug 5,00 Mark / bel Ireier Zuatelluag / losertiona- } \\
\text { prels tar die lantgespalteae Noaparelliezelle } 60 \text { Pleasig }\end{array}$ \\
\hline
\end{tabular}

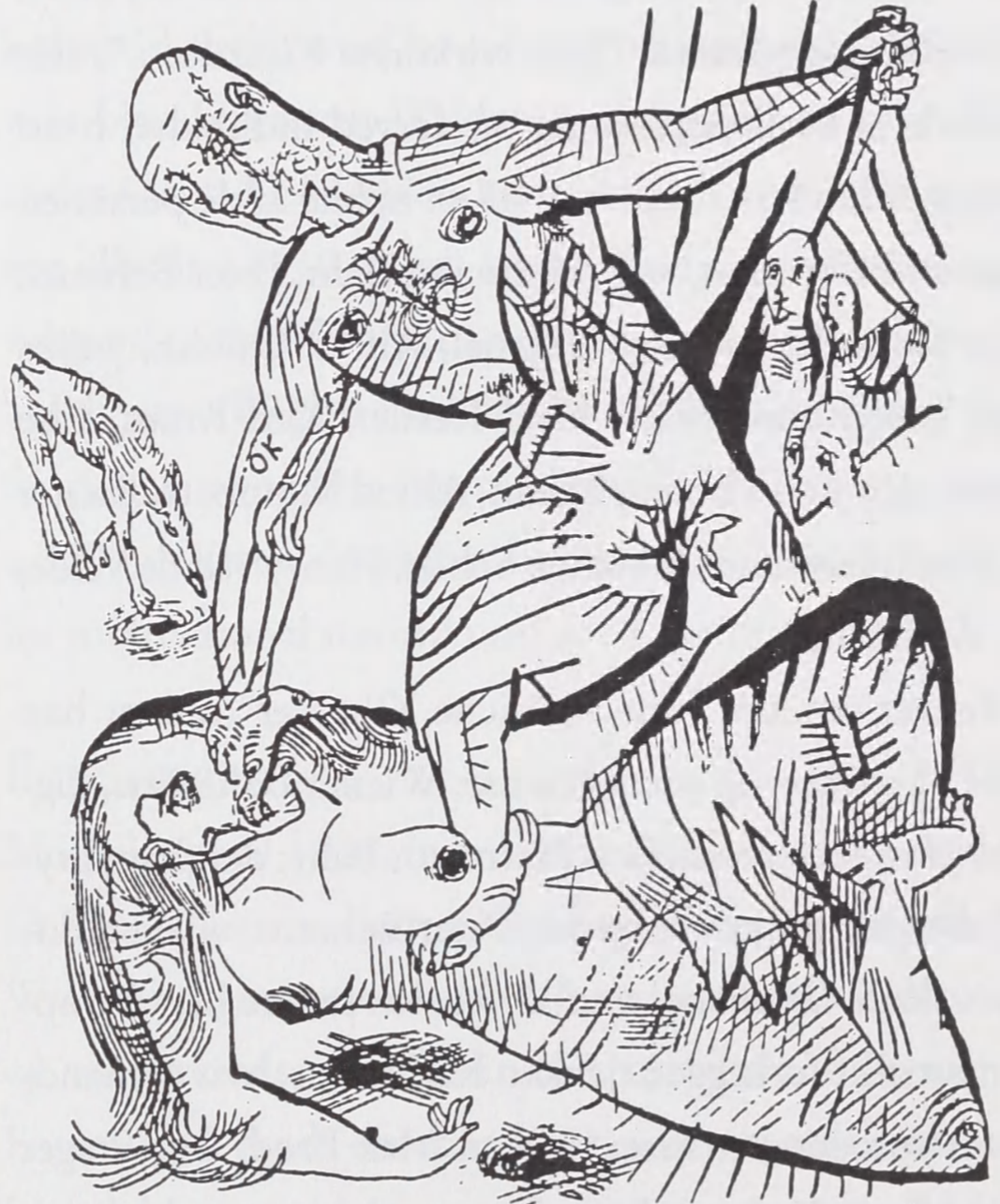

Zeichnung von Oskar Kokoschka zu dem Drama Mörder, Hoffnung der Frauen
INHALT: OSKAR KOKOSCHKA: Mürder, Holfnung der Frauen / PAUL LEPPIN: Daniel Jesus / Roman / ALFRED DOBLIN: Geapriche mit Kalypso liber die Musik / SIEGFRIED PFANKUCH: Liegı der Friede in der Luft / PAUL SCHEERBART: Geyenerklaruny ! KARL VOGT: Ningen als Thealerdirektur \& MINIMAX: Krleysbericht / Karikaturen

Mörder, Hoffnung der Frauen von Oskar Kokosobka

$$
\begin{aligned}
& \text { Mann Personen: } \\
& \text { Frau } \\
& \text { Clior: Männer und W/eiber. }
\end{aligned}
$$

Nachthimnel, Turm mit großer roler ciserner Kálig lur: Facheln das cinzige Licht, schwarzer Buden, so zum Turm sulsiejgend, dals alle Figuren reliel. artig zu selien sind.

Der Mann

WeiBes Gesicht, blaugepanzerl, Stirntuch, Jas eine Wunde bededil, mit der Scliar Jer Mlanuer (wilda Kuple, graue und role koptluyger, weibe, schwarze und braune Kleider, Zeiclien aul den Kleidern, nackie Beene, liolie Facielstangen, Scliellen, Getöse), knechen lieraut mit vorgestreckien Stangen und Liditcri, versuclien mude und unwillig den Abenleurer audulathalien, rethen scin ilcre nieder, er gell vor, sic losen den hirs schreicn.

Männer

W'ir waren das flammende Rad um ilin.

W'ir waren das llammende Rad um dich, Besturmer verschlossener Festungen!

gehen zögernd wieder als kelte nach, er mit dem Fackelträger vor sich, jecht voran.

Màn nor

Fulur' uns Blasser!

W'alirend sie das Plerd nieverreifen wollen, sicigen W'siber mit der Fuhrerin die linke Stiege heraut. Frau rote Kleider, ollene gelbe Hare, groß, Frau laut

Mit ineinem Alem erlladert die blonde Scheibe der Sonne, mein Auge sammelt der Minner Fruhlodien, ihre stammelnde Lust hriecht wie eine Bestie um mich.

Welber

losen sich von ihr los, selien jetzt est den Fremden. Erstes W'cib lüstern

Sein Atem saugt sich grüftend der Jungirau an!

Fra tidsskriftet Morgen 1908, hvor Walden var medredaktør, oplystes endvidere, at man i Verein arrangerede en mindeaften for maleren Walter Leistikow og en musikalsk aften med Arnold Schönberg. 1914/15 gav foreningen 10 Autorenabende med ekspressionistiske digtere i „Sturm Galerie“. Som en del af Der Sturm bestod 
foreningen i 10 år, indtil et godt stykke tid ind i 1920'erne. Herwarth Waldens virke og aktiviteter dækker udtryks- og stilformer som naturalisme, kulturradikalisme, symbolisme, futurisme, ekspressionisme og dadaisme.

Med kendskab til Waldens senere virke med Der Sturm, der begyndte at udkomme 6 år efter, peger dette både frem og tilbage. Han opfordrer virkelige kunstnere til at deltage, men opfordrer samtidig nye talenter til at interessere sig for Verein für Kunst. De virkelige kunstnere var de store navne indenfor naturalismen og symbolismen, der forlængst var blevet klassikere samt de på det tidspunkt højaktuelle Die berliner Moderne. De kommende nye talenter var endnu ikke opdukkede, men med næse for hvad der vil ske, forudsiger Walden anden generation af Die berliner Moderne, ekspressionisterne, en omstændighed, som blandt andet gør Berlin til den interes-santeste by i Europa fra 1910 til et godt stykke ind i 1920'erne. Herwarth Walden bliver primus motor i dette foretagende og allerede persongalleriet i Verein für Kunst åbenbarer Waldens fantastiske evne til at opspore tidens førende personligheder fra ind-og udland. I denne sammenhæng skal vi se de tre danske indbudte.

\section{Brevene}

Og hvad indeholder så brevene? Fra Georg Brandes ligger der i Sturm-Archiv 1 brev med kuvert samt 1 telegram. Brevet er skrevet i København 13. september 1906 og iflg. kuverten afsendt til Berlin dagen efter. I brevet står der: "Hochgeehrter Herr, Ich ahnte nicht, dass Ihr Verein jung ist und keine Geschäfte macht; ich werde auch keine Versuch machen, Sie zu besorgen mir mehr zu geben. Aber ich komme doch nicht zu Berlin. Ich habe nicht das geringster Vergnügen daran, öffentlich zu reden; es ist mir beschwerlich, in fremder Sprache zu reden, und ich bin müde daran, Reisen nach Deutschland zu thun, wo man in der Regel zwei oder drei hundert Mark für einen Vortrag bietet, wovon die Reise und der Hotelaufenthalt reichlich die Hälfte verschluckt. Vor zwanzig Jahren war ich mit diesen Honorar zufrieden, weil die Reise selber mir Spas machte. Jetzt ist es anders. Mit Verzüglicher Hochachtung, Georg Brandes."

Dagen efter må Brandes alligevel have fortrudt, for man modtager om eftermiddagen den følgende dag 1906, 15.09., um 3.55 Uhr et telegram i Berlin på følgende adresse: Herwarth Walden, Ludwigkirch Strasse 12, Berlin, med ordlyden: "Werde dennoch am 18ten Oktober kommen. Brandes." 

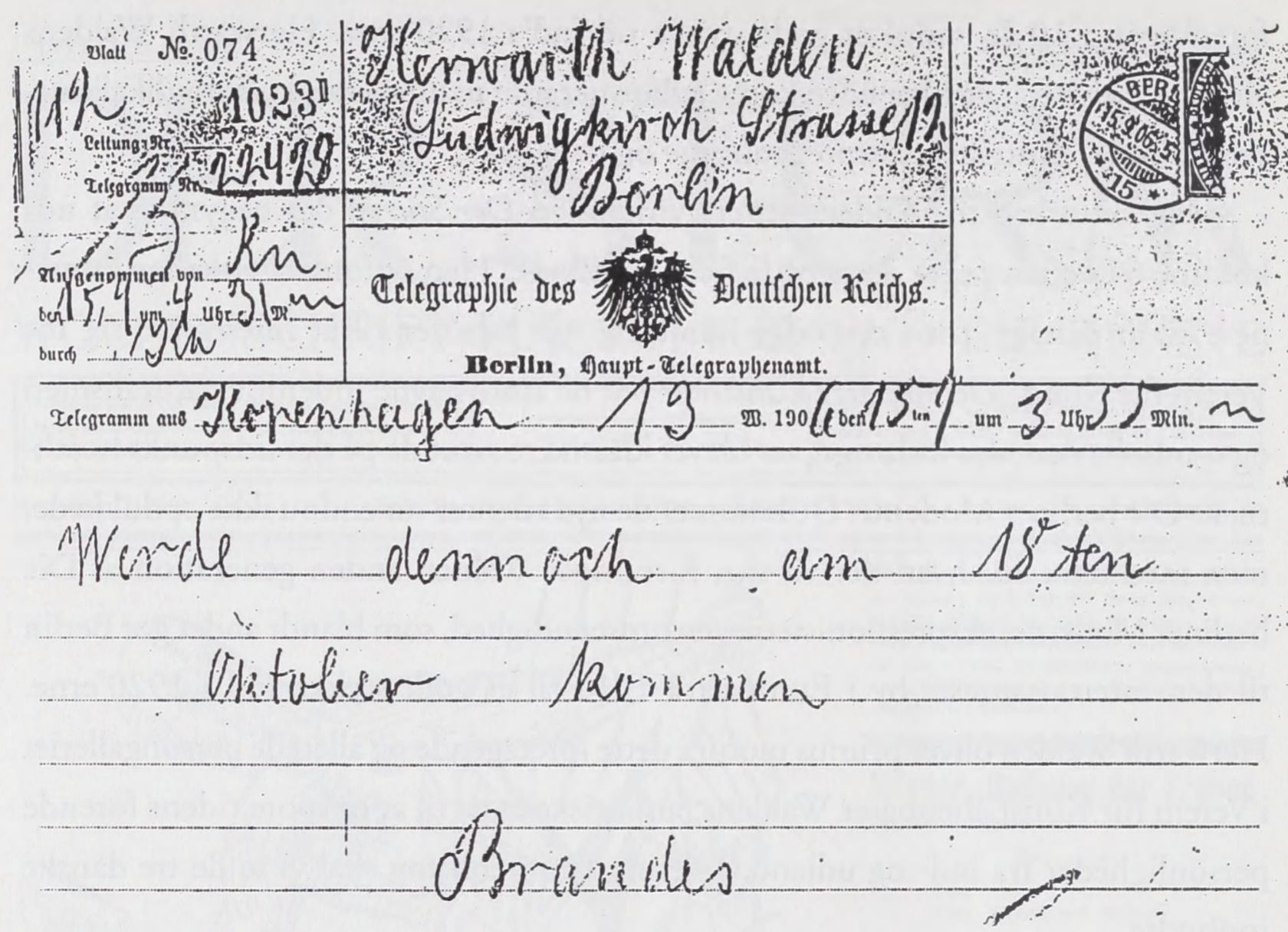

Telegram fra Georg Brandes til Herwarth Walden 15. sept. 1906.

To af brevene fra Herman Bang er fra 1906 og det tredje fra 1908. Kuvert og brev har samme datering, 27. august 1906, fra senere samme år en kuvert med ulæselig datering og med et brev dateret 7. september 1906. Det første brev er afsendt fra Prinsesse Maries Alle 5 i København og brevet lyder som følger: "Sehr geehrter Herr, Ich weiss nicht ganz genau, was ich antworten darf. Denn ich trage eigentlich nicht mehr vor und deutsch vorzutragen wird mir auch recht schwierig sein. Doch ein kleine Sache könnte ich schon vortragen - nach Neujahr, wenn ich noch bis dahin lebe. Zu verzüglicher Hochachtung Herman Bang."

Denne depressive meddelelse synes at fortælle, at Bang har til hensigt at tage til Berlin, og bekræftende er det, at han 7. september 1906 afsender en uddybende meddelelse fra Randers med ordlyden: "Sehr geehrter Herr, Die Antwort ist mir nicht leicht. Dänisch mochte ich am liebsten gar nicht vortragen. Denn in meiner Sprache vorzulesen wenn absolut niemand versteht, wurde mir peinlich sein. Ich will aber jetzt versuchen, ob ich „Des Meisters Tod“ - den Schluss von „Michael“ deutsch einstudieren lassen und dann diese Sterbescenen vorzutragen. Was der Recitator liest ist mir recht egal. Denn ich weiss ja nicht, wer der Mann sein wird 
und was er zu leisten im stande ist. Der 24 Januar wurde recht gunstig sein. Doch niemand weiss, ob man so lange lebt. Ihr ganz ergebenes Herman Bang."

To år senere, efteråret 1908, 9. september, er Bang igen blevet opfordret til at læse i Berlin. Her er svaret prompte: "Sehr geehrter Herr, Ich kann nicht nach Berlin gehen. Überhaupt trage ich nicht vor, wo man mir nicht ein Honorar von 300 Mark bieten kann. Es strengt mich allzu sehr an. Bien à vous. Herman Bang."

Fra samme år 1908 stammer to breve fra Johannes V. Jensen, svar på den samme indbydelse som de foregåendes. Johannes V. Jensen svarer på dansk. 2. juli 1908 lyder det: "Hr. Herwarth Walden, Hiemkommen fra en længere Rejse finder jeg til min Beklagelse, at et brev fra Dem har ligget og ventet paa mig og saaledes ikke har faaet min Besvarelse, jeg beder Dem meget undskylde. For Tilbudet takker jeg, det er venligt af Dem og overordentligt smigrende at ville have mig ned og læse op for et tysk Publikum; jeg vil ogsaa gerne og tror at jeg nok kunne indøve nogle stykker pa Tysk. Men det er mig ikke muligt nu at give noget bestemt Svar. Visse gennemgribende Ting, der skal komme til Afgørelse i den nærmeste Tid forhindrer mig i foreløbigt at tage Bestemmelse, jeg ved ikke om jeg vil blive bundet her eller bliver fri til vinter, saa at jeg kan reise. Forhaabentlig vil jeg kunde vide enten-eller om en Maanedstid. Jeg beder Dem disponere ganske som det passer Dem, indtil De hører fra mig, og haaber De tilgiver det sene Svar. Med Undskyldning for at jeg skriver Dansk. Deres ærbødige Johannes V. Jensen Jacobys Alle 2, Kopenhagen"

21. september 1908 sender Johannes V. Jensen afbud med følgende ordlyd: "Hr. Herwarh Walden, Det gør mig ondt at maatte meddele Dem at jeg har set mig nødsaget til at opgive mit Besøg i „Verein für Kunst“, i alt fald for i Aar. Man har givet mig grund til at tro at Jeg, ukyndig som jeg er i Tysk, kun vilde misbruge et tysk Publikums Taalmodighed. Idet jeg beder Dem undskylde at jeg saa sent har taget denne Bestemmelse, der er definitiv, er jeg Deres højagtelsesfulde ærbødige Johannes V. Jensen". Dette brev af 21. sept 1908 findes i arkivet i tysk oversættelse.

\section{Var Brandes prædadaist?}

Af brevene lader det til, at Brandes tager til Berlin for at læse af egne værker i Berliner Architektenhause 18. oktober 1906. Hvad han har tænkt sig at læse, vides ikke. Herman Bang har sandsynligvis læst i Verein für Kunst på den af ham opgivne dato 24. januar 1907 og kan have læst den af ham opgivne, på tysk indstuderede passage af slutningen af Michaël: Des Meisters Tod, dødsscenen. Om han under- 


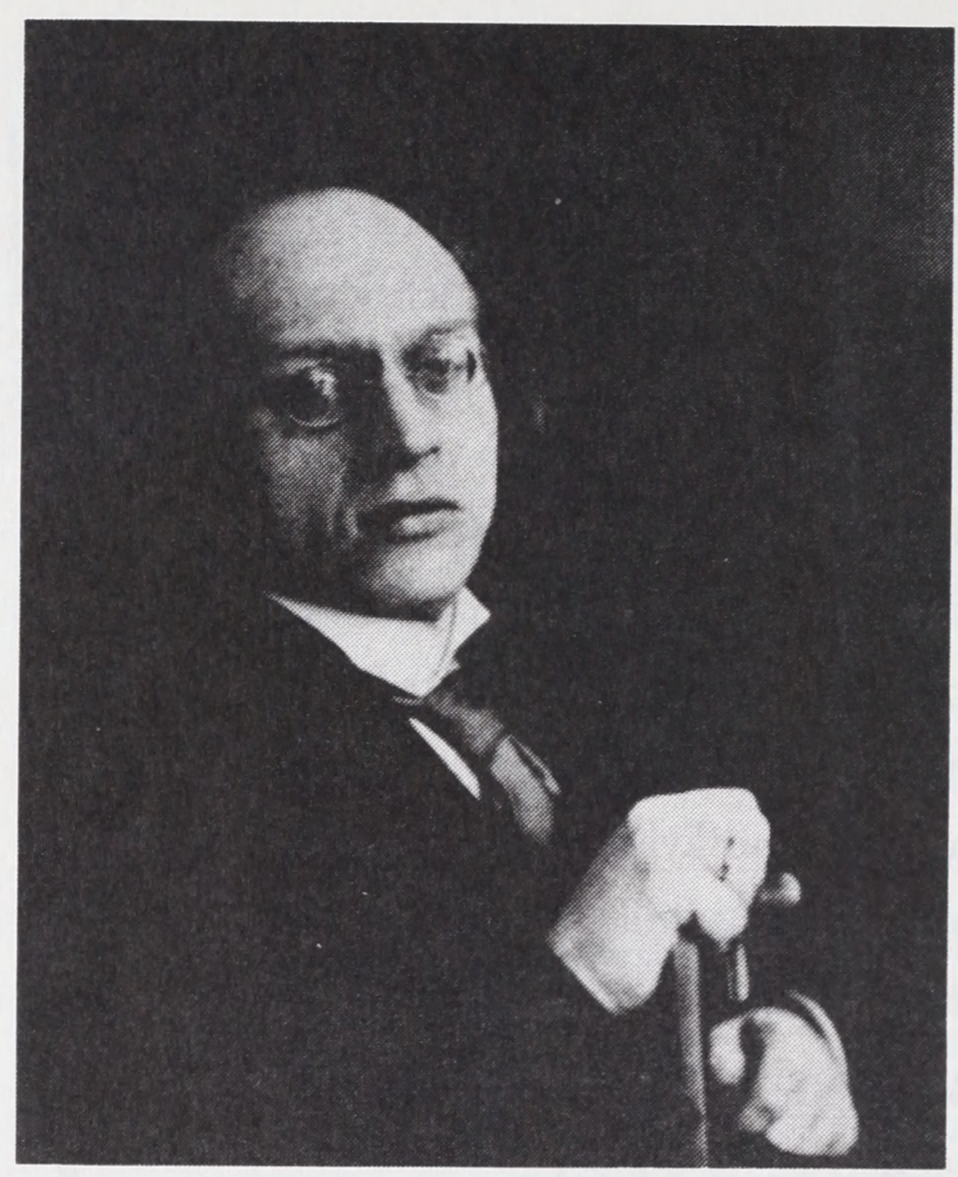

Herwarth Walden i 1915.

støttes eller ledsages af den af Walden foreslåede recitator vides ikke. Johannes V. Jensen udsætter afgørelsen i første omgang, fordi han kan stå foran vigtige afgørelser, der vil forhindre ham i at rejse, i anden omgang afslår han, fordi han har fået grund til at tro at han vil misbruge et tysk publikums tålmodighed på grund af ukyndighed i tysk.

Det, der er interessant, er at man fra Berlin på dette tidspunkt i et så specielt regi som Herwarth Waldens sender bud efter danskerne. Hvilket for Brandes' vedkommende ikke er så underligt endda; han var kendt i Tyskland og specielt i Berlin, hvor han havde opholdt sig fra 1877-1883 og havde udgivet samlingen: Berlin som tysk Rigshovedstad, Erindringer fra et femårigt Ophold, Kiøbenhavn 1885. Både Georg Brandes og Herman Bang er fortsat medlemmer af Waldens kulturgarde og dukker op i tidsskriftet Der Sturm i 1910. Georg Brandes optræder i en ironisk kommentar i 1. årg. nr. 46 under titlen: Wie Georg Brandes Hilde Simon kämpfte. For Bang annonceres der i 1. årg. nr. 1 i en annonce for Beachtenwerte Bücher und Tonwerke for bogen Menschen und Masken, Verlag Hans Bondy i Berlin. Samtidig bringes i 1. årg. nr. 16: Die Väter essen Herlinge (Zu Gustav Wied) og i 2. årg. nr 46: Honore de Balzac.

Og så bryder modernismen for alvor igennem. Walden flytter 1912 med Redaktion der Sturm fra Berlin-Halensee til det dengang meget driftige kvarter omkring 
Potsdamerstrasse og Potsdamerplatz. Og han udvider med oprettelsen af Der Sturm Galerie i Gilka-villaen i Tiergartenstrasse som indrettes til kunstudstillinger fra marts 1912. Han åbner med en udstilling med Der blaue Reiter mm. Walden bliver fra da af Wegbereiter der Moderne. I den egenskab starter han sine europæiske turneer og kommer da også personligt til København. Allerede juli 1912 vises Der Sturms udstilling af de italienske futurister i den Frie Udstillingsbygning. Herwarth Walden er selv tilstede. Maj 1913 er Walden igen i København med kubister og ekspressionister i Københavns Kunstsalon i Bredgade, og ved åbningen giver han en pressekonference.

Senere har to danske kulturradikale kontakt med tidsskriftet og galleriet i Berlin idet Robert Storm-Petersen publicerer to originaltræsnit i Der Sturm årgang 1913. Senere efter 1. verdenskrig deltager Storm-P. i en udstilling i Sturm Galerie april 1923 sammen med Emilio Pettoruti. Endelig publicerer Broby Johansen i Der Sturm 1928 Gruss an Dürer, over Albrecht Dürers skrift Unterweysung der Messung, Dürer som den første kubist, befriet for al metafysisk overbygning.

$\mathrm{Ja}$, Brandes var prædadaist.

Konsulteret materiale

Sturm-Archiv, Handschriftabteilung, Staatsbibliothek zu Berlin, Preussischer Kulturbesitz, Potsdamerstrasse 33.

Tidsskriftet Der Sturm, Berlin 1910-32.

Materiale angående de nye forhold i Berlin efter 2. Jan.1992 bl.a. Die Stiftung Preussischer Kulturbesitz, Teil I, Berlin 1994.
Georg Brühl: Herwarth Walden und der Sturm, Leipzig 1983.

Katalog Herwarth Walden 1878-1941 Wegbereiter der Moderne, Berlinische Galerie, Martin Gropius Bau 1991.

Die Berliner Moderne 1885-1914 (ed. J. Schutte und P. Sprengel) Stuttgart 1987. 